\title{
AOR
}

Selected Papers of \#AolR2020:

The $21^{\text {st }}$ Annual Conference of the

Association of Internet Researchers

Virtual Event / 27-31 October 2020

\section{BETWEEN LIVE AND LIFE: EXPLORING THE ONLINE PRESENCE OF PERFORMANCE ARTISTS}

\author{
Laura Gemini \\ University of Urbino \\ Stefano Brilli \\ University of Urbino
}

\section{Introduction}

This paper explores the use of social media by Italian contemporary theatre artists and companies. The study aims to explore the relational labour (Baym 2018) of performance artists in tracing the boundaries between online/offline performativity and between personal self-narration and artistic promotion. Through a combination of profile analysis and in-depth interviews, we want to understand how this artistic scene - that always experimented on intermedial and participatory possibilities - is making sense of social media. This reflection becomes crucial in the moment we are witnessing what some have called an "ephemeral turn" in digital media (Haber 2019). The shift from contents permanence as a default condition, to the multiple temporalities of stories and video streams, opens a new strand of possibility for relations between social media and performativity that are to be explored.

\section{Theatre and social media: Between promotion and performative practices}

In the last decade, the use of social media in the theatre scene has fueled debates on the possibility to redefine the performer-audience relationship on a wide scale (Lonergan 2015). In the context of mainstream-mainstage theatre, this possibility has been initially explored mostly through Twitter. For example, with the experimentation of live-tweeting during performances with particular "tweet seats" (Ahmed 2011), or through the crossmedia transfer of classic drama, as in the often-cited case of Such Tweet Sorrow (Royal Shakespeare Company, 2010).

These cases represent an initial phase characterised by a "fascination" with the medium. However, as Bree Hadley (2017) analysed, the relationship between theatre Suggested Citation (APA): Gemini, L., Brilli, S. (2020, October). Between Live and Life: Exploring The Online Presence Of Performance Artists. Paper presented at AolR 2020: The 21 $1^{\text {th }}$ Annual Conference of the Association of Internet Researchers. Virtual Event: AolR. Retrieved from http://spir.aoir.org. 
and social media now concerns a much broader spectrum of meaning-making possibilities that arise around performances. In her study Hadley traces at least six areas in which we can currently observe the impact of social media in the theatrical field: 1 ) in the use of social media for the construction of intermedial performances, 2) in the dissemination of performances, 3 ) in the processes of audience development, 4) for the critics' public, 5) for documentation and archiving, and 6) in the performative aspects concerning the daily use of social media.

One of the main themes framing the debate on theatre and social media is the emphasis on their democratising potential, especially on the possibility that they have to reach marginalised audiences otherwise excluded from the orbit of contemporary theatre (Sant 2014; Walmsley 2019). According to Balme (2014), social media can amplify the range of debates developed within theatre outside the "closed circuit of subscriber audiences, professional reviewers and theatrical unions" (Balme 2014, p. XI).

Research on the "expansive" potential of social media on theatre have produced contradictory outcomes (Walmsley 2019). One problem is their actual ability to breach the calcified margins of western canons and connoisseurs' networks. In this regard, O'Neill (2014) notes in his study of Shakespeare's diffusion on YouTube that nonEuropean adaptations are almost absent from search results without racial appellations such as "African", "Asian" or "Pacific".

Alongside the possibilities for the expansion of theatre "outside of itself", the relationship between theatre and social media is also to be observed in terms of the new forms and protocols shaping the online circulation of theatre. One example is the diffusion of theatre promotional videos (Vollans 2015) for which social media represent the main distribution infrastructure. This phenomenon has to be located within the reshaping of the relationship between theatre texts and para-texts highlighted by Conner (2013). This process entails an incremental centrality in the audiences meaning-making operations with those elements that are external to the performance yet becoming more persistent and searchable thanks to social networks affordances.

How the daily online presence of performance artists and companies relates to the para-textual corpus of performance is still a theme barely explored by literature, but central to the present analysis. Addressing this issue becomes particularly necessary, considering how the development of social media constitutes a drive towards the aestheticization of everyday life (Gemini 2009), where performativity enters personal self-narrations (Lavender 2016).

Observing this process solely as a collapse of the boundaries between performance and the mundane proves to be a short-sighted perspective, as it does not account for the way theatre artists work to establish the margins of their role within a media-based environment. As Nancy Baym (2018) observes in her study on how musicians manage the artist-fan relationship, the increasing use of social networks entails for artists an increasingly high level of relational work. Such a task configures as a constant and demanding emotional effort to manage the frontiers between artistic work, private life and personal exposure. Where the interaction with fans can no longer rely only on the boundaries provided by classic rites and infrastructures of performance (such as the stage, the concert situation etc.), performers must experiment the most appropriate ways to control the interaction. 
The mediatization of theatre communicative relationships, observable through social media, goes beyond the problem of including new audiences. It implies defining the relationships with users, spectators and fans, which is now likely to become an integral part of their work routines.

\section{Methods}

Given this scenario, our study asks:

R.Q.1: How contemporary theatre companies manage the boundaries between online promotion and artistic experimentation on the medium?

R.Q.2: How contemporary theatre artists manage the boundaries between online selfperformance and the performativity related to their theatre practices?

To approach these questions, we conducted 1) in-depth interviews with 20 of the most significant companies of the Italian contemporary theatre scene which are involved in intermedial practices and 2) a content analysis of their Facebook profiles and Instagram profiles, coding for each post a) object promoted (theatre performance/other activity/not promotional), b) members of the company portraited, c) work/life boundary (related to theatre work or else), d) company/community boundary (related to the company or to other colleagues work).

\section{Preliminary results}

Preliminary results show how social media interaction and content production is becoming an integrated part of performance artists' working routines. Companies position their social media activity outside a purely promotional logic. This antipromotional ethos translates to a lack of efficacy in terms of strategic communication. However, it also lays the basis for the use of social media to expand performative practices. Although the interviewed companies do not exclude such a possibility, they lament their current inability in making such an attempt. Lacking resources is the most quoted explanation of this failure, followed by the refusal to compromise with the constraints of online languages, and the distrust of social media to reach wider audiences.

\section{References}

Ahmed, B. (2011) "Tweet Seats" Come to Theaters, But Can Patrons Plug In without Tuning Out?. National Public Radio, 12 December 2011, 


\section{http://www.npr.org/sections/monkeysee/2011/12/12/143576328/tweet-seats-come-}

totheaters-but-can-patrons-plug-in-without-tuning-out

Balme, C. B. (2014). The theatrical public sphere. Cambridge University Press.

Baym, N. K. (2018). Playing to the Crowd: Musicians, Audiences, and the Intimate Work of Connection. New York University Press.

Conner, L. (2013). Audience engagement and the role of arts talk in the digital era. New York: Palgrave Macmillan.

Haber, B. (2019). The digital ephemeral turn: queer theory, privacy, and the temporality of risk. Media, Culture \& Society, 41(8), 1069-1087.

Hadley, B. (2017). Theatre, Social Media, and Meaning Making. Cham: Springer International Publishing.

Gemini, L. (2009). Stati di creatività diffusa: i social network e la deriva evolutiva della comunicazione artistica. In Mazzoli L. (Ed.) Network Effect. Quando la rete diventa pop. Torino: Codice. 113-136.

Lavender, A. (2016). Performance in the twenty-first century: Theatres of engagement. London: Routledge.

Lonergan, P. (2015). Theatre and social media. Basingstoke, Hampshire : Palgrave Macmillan.

O'Neill, S. (2014). Shakespeare and YouTube New Media Forms of the Bard. London: Bloomsbury Publishing.

Sant, T. (2014). Art, Performance, and Social Media. In Hunsinger J. \& Senft T. (Ed.) The Social Media Handbook. London: Routledge. 53-66.

Vollans, E. (2015). Cross media promotion: Entertainment industries and the trailer (Doctoral dissertation, University of East Anglia). 
Walmsley, B. (2019). Audience engagement in the performing arts: A critical analysis. Basingstoke, Hampshire : Palgrave Macmillan. 